\title{
CAEDUALLA REX BRETTONUM AND THE PASSING OF THE OLD NORTH ${ }^{1}$
}

\author{
Alex Woolf
}

University of St Andrews

IN THE TWENTIETH CHAPTER of the second book of his Historia Ecclesiastica the eighth-century Northumbrian scholar Bede introduces the reader to Caedualla rex Brettonum. ${ }^{2}$ Caedualla is notable as one of only two British secular rulers to be named in $H E$, if we discount Ambrosius Aurelianus, the apparently fifth-century commander, alluded to in a passage lifted almost verbatim from the work of Gildas. ${ }^{3}$ While Bede is undeniably our leading narrative source for British history in the seventh and eighth centuries he is decidedly taciturn on the subject of the Britons who, for much of the period he covers, may well have made up the majority of the population not only of the island as a whole but in many of the Anglo-Saxon kingdoms the development of which form his primary concern. ${ }^{4}$ Whether Bede's silence on British history is the result of 'conspiracy' or simply 'disciplined focus' is open to debate. $^{5}$ For this reason his account of Caedualla is of particular interest.

Caedualla's floruit within the pages of the Historia Ecclesiastica runs from II, 20, in which he rebels against the Deiran King Edwin, slaying him, and III, 1, in which he himself is slain by the Bernician ruler Oswald. Immediately before the account of the latter event Bede also tells us that the British King was responsible for the killing of two intermediate rulers of Deira and Bernicia, Osric and Eanfrith. ${ }^{6}$ In the early ninth

\footnotetext{
1 It is conventional to render the name of this King in its modern Welsh form Cadwallon. Here the forms found in the primary texts will be preserved in order that the distinction between the information contained in different sources can be better maintained. Thanks go to Thomas Owen Clancy and Dauvit Broun for reading drafts of this paper in advance. Errors and eccentricities remain my own.

${ }_{2}$ Bede's Ecclesiastical History of the English People, ed. and trans. B. Colgrave and R. A. B. Mynors (Oxford, 1969) [henceforth $H E]$ II. 20.

${ }^{3} H E$ I.16, following Gildas, De Excidio Brittaniae $\$ 25$. I am following Michael Winterbottom’s edition, Gildas: the Ruin of Britain and Other Works (Chichester, 1978). The other British ruler named by Bede is Cerdic, at whose court the Deiran ætheling Hereric was exiled, at $H E$ IV.23. He is usually identified with the Certic named as king of Elmet in $H$ (istoria) B (rittonum) 63 (see below fn. 7).

${ }^{4}$ For general discussions of the survival of Britons within Northumbria see M. Faull, 'British Survivals in AngloSaxon Northumbria', in Studies in Celtic Survival, ed. L. Laing (Oxford, 1977), pp. 1-55 and N. J. Higham, 'Britons in Northern England in the Early Middle Ages: Through a Thick Glass Darkly', Northern History, XXXVIII (2001), $5-25$.

${ }^{5}$ For a discussion of this issue see T. M. Charles-Edwards, 'Bede, the Irish and the Britons', Celtica, xv (1983), $42-52$.

6 HE III.1.
}

(C) The University of Leeds, 2004 
century the author of the Cambro-Latin text Historia Brittonum ascribed Edwin's defeat to exercitu Catguollauni, regis Guendotae regionis. ${ }^{7}$ The same author, describing Oswald's victory, says of the Bernician that he occidit Catgublaun, regem Guenedotae regionis. ${ }^{8}$ These references to our king are found in only two of the extant manuscripts of Historia Brittonum, British Library, Harleian MSS, 3859, from c. 1100, and the closely related Cotton MSS, Vespasian DXXI from the twelfth century, although it is widely held that they were part of the 'primary' text. ${ }^{9}$ All subsequent commentators have accepted this identification and most have gone further and identified the king with that Catgollaun map Catman who appears in the pedigree of Ouen map Higuel (Owain son of Hywel, $\uparrow 988$ ) preserved in the collection of Welsh genealogies appended to the recension of $H B$ preserved in Harleian MSS, 3859. ${ }^{10}$ It is the purpose of the present paper to re-examine these identifications and to suggest a possible alternative interpretation of the events described by Bede than that which has been developed upon the basis of them. The initial step in this process must be to examine the different early medieval sources for this individual, or these individuals, in turn.

The earliest appearance in a prose narrative of the British King mentioned by Bede pre-dates the publication of $H E$ by a generation. The Vita Columbae of Adomnán, composed, probably, in the 690s, relates how Oswald beheld a vision of Columba the day before his battle contra Catlonem Britonum regem fortissimum..$^{11}$ Adomnán gives no more details of the Briton's descent or provenance but, for what it is worth, alludes to the battle as if it would be well known to his readership. Perhaps also originating in seventh-century Iona are the notices in the Irish chronicles. For the mid seventh century these may be contemporary notices although we cannot be assured of this. ${ }^{12}$

The Annals of Ulster note at 631 [recte 632] Bellum Cathloen, Regis Britonum, 7 Anfrith, apparently the killing of Eanfrith of Bernicia dated by Bede to 634 and by David Kirby to $635 .{ }^{13}$ In the Annals of Tigernach the equivalent entry reads Cath la Cathlon 7 Anfraith qui decollatus est, in quo Osualt mac Etalfraith uictor erat et Catlon, rex Britonum, cecidit. ${ }^{14} A T$ has clearly run together Eanfrith's killing with its sequel, Oswald's victory, but whether this is due to faulty transmission of the original

\footnotetext{
7 'army of Catguollaun, king of the region of the Venedotians', Historia Brittonum, $\$ 61$. Here cited from the edition of John Morris, Nennius: British History and the Welsh Annals (Chichester, 1980), but with my translation. Scholarly consensus has been persuaded by David Dumville's arguments in "Nennius" and the Historia Brittonum', Studia Celtica, X/XI (1975/76), 78-95, that 'Nennius' was not the author of this work. For a spirited defence of Nennius's authorship see P. J. C. Field, 'Nennius and his History', Studia Celtica, xxx (1996), 159-65. Field's anxieties are echoed by T. O. Clancy in 'Scotland, the 'Nennian' recension of Historia Brittonum, and the Lebor Bretnach', in Kings, Clerics and Chronicles in Scotland, 500-1297: Essays in honour of Marjorie Ogilvie Anderson on the occasion of her ninetieth birthday, ed. S. Taylor (Dublin, 2000), pp. 87-107, especially at p. 98, n. 5.

${ }^{8} H B \S 64$, again following Morris.

9 'Historia Brittonum cum additamenti Nennii', ed T. Mommsen in Chronica Minora saec. IV. V. VI. VII (Berlin, 1891-98), vol. 3, 111-222.

${ }_{10}$ Printed in $E$ (arly) $W($ elsh $) G($ enealogical) $T($ racts), ed. P. C. Bartrum (Cardiff, 1966), p. 9.

11 Adomnán's Life of Columba, ed. A. O. Anderson and M. O. Anderson (Edinburgh, 1961 and Oxford, 1991) [henceforth $V C$ ], I.1. For a more recent translation with extensive notes see R. Sharpe, Adomnán of Iona: Life of Columba (Harmondsworth, 1995).

${ }_{12}$ K. Hughes, Early Christian Ireland: an introduction to the sources (1972).

${ }_{13}$ The A[nnals of] U[lster (to A.D. 1131)], ed. S. Mac Airt and G. Mac Niocaill (Dublin, 1983); HE III.1; D. P. Kirby, 'Bede and Northumbrian Chronology', English Historical Review, LXXVIII (1963), 514-27.

${ }_{14}$ The A(nnals of) T(igernach), vol. 1, ed. W. Stokes (Felinfach, 1993), p. 142, reprinted from Revue Celtique, XVII (1896), 182.
} 
chronicle entries or because the second event followed hard upon the first, and was associated with it by the time word reached the annalist, is unknowable. What is perhaps interesting to note is $A T$ 's assertion that Eanfrith was beheaded, echoing, perhaps Bede's use of the word damnavit to describe the fate meted out to the Bernician king by Caedualla. ${ }^{15}$ Was there a judicial aspect to this killing, perhaps associated with Eanfrith's alleged apostasy? In any case, once again, there is no indication of the place of origin or paternity of Caedualla.

This brings us once more to the Historia Ecclesiastica. The Briton is introduced after the summary of Edwin's reign, rebellauit aduersus eum Caedualla rex Brettonum, auxillium praebente illi Penda uiro strenuisimo de regio genere Merciorum..........et conserto graui proelio in campo qui uocatur Haethfelth occisus est Eduini. ${ }^{16}$ One point of interest in this account is that Penda is said to have helped Caedualla in his rebellion rather than to have joined him. The usual interpretation of this passage has been that Edwin as overlord of all Britain was faced with a rebellion of an assortment of subject kings of whom Caedualla was the leader. It is not altogether clear that this is the case and it may be that Penda's later conflict with the Bernician dynasty has influenced this reading. The sequel is also of interest. The subsequent account of atrocities committed against ecclesia uel gente Nordanhymbrorum are attributed to Caedualla alone as are the subsequent dealings with the three northern Kings, Osric, Eanfrith, and Oswald. Bede tells us that in the course of the battle one of Edwin's son, Osfrith, was slain prior to his father and that the other, Eadfrith, ad Penda regem transfugit. ${ }^{17}$ All of this could bear the reading that this was essentially a northern conflict of which Penda was an interested observer rather than a prime mover. Indeed it hints that Edwin's imperium was made up of an inner core of subservient kingdoms surrounding Deira and an outer shell including Mercia and extending necnon et Meuanias Brettonum insulas. ${ }^{18}$

Bede's description of the relations of Osric of Deira and Eanfrith of Bernicia with Caedualla also have the appearance of 'local' northern affairs. We are told that Osric met his fate in the following summer (Edwin had been killed in mid October) when he besieged Caedualla in an oppido municipio. The Britons sallied out, taking Osric and his army by surprise and destroying them. ${ }^{19}$ Oppidum is not a word commonly used by Bede, and James Campbell has suggested that he only used it when dependent upon written source material. If Bede had believed, as many modern commentators have done, that the place intended was York then he would presumably have used the word civitas to describe the place, as he did in all other instances. ${ }^{20}$ The question we

\footnotetext{
15 III.1.

16 'Caedualla, a king of the Britons, rebelled against him, help was given him by Penda an energetic man of the royal race of the Mercians. ... and they joined together in fierce battle on the plain called Hatfield, Edwin is killed.' $H E$ II.20.

17 'Fled across to King Penda', ibid.

18 'and even to the Mevanian [sic] isles of the Britons', HE II,5. For such 'inner' and 'outer' zones in the Mercian hegemony see Charles-Edwards, 'Wales and Mercia, 613-918', in Mercia: an Anglo-Saxon Kingdom in Europe, ed. M. P. Brown and C. A. Farr (2001), pp. 94-95.

19 HE III.1.

20 J. Campbell, 'Bede's Words for Places', in Places, Names and Graves, ed. P. Sawyer (Leeds, 1979), pp. 34-54, reprinted in J. Campbell, Essays in Anglo-Saxon History (1986), pp. 99-120; Glanville Jones, 'Multiple Estates and Early Settlement', in Medieval Settlement: Continuity and Change, ed. P. H. Sawyer (1976), p. 38, n. 3, has suggested that this place was Aldborough, ancient Isurium, but Campbell's caveat would also exclude this identification.
} 
have to ask ourselves in relation to this episode is how we imagine the period immediately prior to the siege. What was the nature of Osric's relationship with Caedualla between Edwin's death and his own? Had Osric been living in the bush conducting a guerrilla campaign against an occupying power? Had he in fact led an invasion of Gwynedd? Had he led an expedition into an immediately adjacent region to his own kingdom to exact vengeance? Our answer to these questions must depend to some extent upon how we imagine warfare to have been conducted in this period. Is it realistic to imagine a king of Gwynedd over-wintering so far from home? Or for a man who only leads his men as some sort of guerrilla captain, and who loses his life in his only set piece encounter with the enemy, to be regarded as a king, as Osric was? Neither of these propositions are impossibilities but they are far from probabilities and perhaps not even plausibilities.

Eanfrith's fatal encounter with Caedualla also suggests that we are dealing with 'local' history. The Bernician King went to visit the Briton with only a small number of companions (Bede's xii lectis militibus may be biblically inspired in detail) and was slain, perhaps, as we have seen, executed. Eanfrith's successor then led a small force to confront Caedualla and was victorious near Hexham. ${ }^{21}$ Cumulatively we have a series of events that all seem to take place in the territory of what was to become Northumbria over the course of about a year, beginning in October 633 or $634 .{ }^{22}$ Were Bede our only source for the period we should probably be in no doubt that Caedualla was a north British ruler, perhaps one of those whose kingdoms were said to have been reduced to tributary status by Æthelfrith of Bernicia. ${ }^{23}$

This brings us back to Harleian MSS, 3859, containing the best witness of that recension of $H B$ which deals with these events, the earliest collection of Welsh pedigrees and also the earliest surviving version of the Annales Cambriae. The first of the two passages in $H B$ which concern us, $\S 61$, is a pedigree of the Deiran royal house ending with a brief note concerning its demise at the hands of Catguollauni regis Guendotae regionis. The second allusion to these events occurs in \$64, part of a passage consisting of an annotated, post-union, Northumbrian king-list. Both these sections, while annotated by the author, are clearly based, like much of the other material in $H B$, on a collection derived from English sources. Indeed $\$ \S 57$ to 65 are simply an attempt to synchronize a small number of native British narrative details with a superstructure derived from a collection of Anglian pedigrees, a Northumbrian king-list similar to that preserved in the Moore Memoranda, but not identical with it, and probably a copy of $H E$ itself. ${ }^{24}$ Understanding these relationships allows us to recognize that the references to the exercitus Catguollauni in $\S 61$ and to Catgublaun in $\S 64$ are minor authorial editions to the material imported from Northumbrian sources. They represent a synchronism of Welsh and English material that took place not long before the publication of $H B$ in $829 / 30$. One should also note that the phrase

$21 H E$ III. 2.

${ }^{22}$ For the dates see Kirby, EHR, LXXVIII, 514-27.

23 HE I. 4.

${ }^{24}$ D. N. Dumville, 'On the North British Section of the Historia Brittonum', Welsh History Review, vIII (1977), 345-54. On the dependence on $H E$ see also D. N. Dumville, 'Historia Brittonum: an Insular History from the Carolingian Age', in Historiographie im frühen Mittelalter, ed. A. Scharer and G. Scheibelreiter (Oldenbourg: München, 1994), pp. 406-34. 
used to identify the British king in both these passages, regis Guendotae regionis (§61) and regem Guenedotae regionis (\$64), also appears in the account of Catgabail rex Guenedotae regionis (\$65) and is echoed in the account of Maelgwn who is described as magnus rex apud Brittones ... id est in regione Guenedote (§62). In this last instance we can be fairly certain that the allusion to Gwynedd is a clarificatory gloss introduced by the author where his source, whatever that was, simply referred to Maelgwn as 'a great king among the Britons'. One might infer from this that the rather verbose style 'in the region of the Venedotians' is authorial, and that it has been added to the accounts of Northumbrian history by the author rather than by some intermediate hand. ${ }^{25}$ This suggests that the only significant authorial contribution at this point was the identification of the place of origin of one of the characters he found mentioned in his Northumbrian source. The question this leads us to is what was the nature of the source material that the author of Historia Brittonum had to hand on the Welsh side?

The only surviving native Welsh chronicle of the early middle ages, the Annales Cambriae, seems to have originated at roughly the same time as the Historia Brittonum, some time in the late eighth or early ninth centuries, since its core appears to be a chronicle kept at St Davids between $c .795$ and $c .954 .{ }^{26}$ This survives, as we have seen, in a MS. of $c .1100$, and it is therefore possible that it has been interpolated at one or more stages between 954 and the date of the production of the MS. The chronicle itself contains entries covering, intermittently, the period between 447 and 795 drawn from a variety of sources, some identifiable and others not. Unfortunately we cannot tell whether all or any of these early entries predate the compilation of the exemplar to the present MS. c. 954 or, indeed, if some of them were added as late as the production of the extant MS. The seventh-century entries, by and large, seem to bear a close relationship with the extant version of $H B$ although a number of notices record information not found either there or in the Irish chronicles which have lent much of the earlier material. Most, perhaps all, of these Irish entries derive from the Clonmacnoise group of chronicles which gained their distinctive features after 911.27 This relationship suggests that all of the pre-795 material was added to the chronicle in the tenth century. Of the independent Welsh entries, one, obsessio Catguollaun regis in insula Glannauc, is of particular interest here.$^{28} \mathrm{It}$ is the only notice of an obsessio in

\footnotetext{
${ }^{25}$ That one could describe Gwynedd in other ways is indicated by $H B \S 40$ 's ad regionem quae vocatur Guined. For a discussion of this usage see D. N. Dumville, 'Notes on Celtic Latin', Bulletin of the Board of Celtic Studies, xxx (1983), 285-86. It should also be noted that there is a grammatical problem here arising from the Latinization of the underlying Welsh form. While Guenedotae is clearly a genitive singular (agreeing with regio) the stem is from the Welsh plural form for an inhabitant of Gwynedd, cf. modern Welsh Gwyndod. It should perhaps be noted that Annales Cambriae[see next note] s.a. 809 notes Elbodug archiepiscopus Guenodotae regione migravit ad Dominum suggesting, perhaps that the apparently intrinsic linking of the word regio with Guenedote may reflect an association of our author with the necessarily territorial interests of the episcopate.

${ }^{26}$ For a critical edition see E. Phillimore, Y Cymmrodor, IX (1888), 141-83. A more accessible edition and translation (with little apparatus or explanation) can be found in Morris, Nennius. For an analysis of the construction of the chronicle see K. Hughes, 'The Welsh Latin Chronicles: Annales Cambriae and related texts', Sir John Rhws Memorial Lecture, Proceedings of the British Academy, LIX (1973), 3-28, reprinted, along with the 'A-text' of the Annales Cambriae in idem, Celtic Britain In the Early Middle Ages (Woodbridge, 1980).

${ }^{27}$ For a full exposition of these relationships see K. Grabowski and D. N. Dumville, Chronicles and Annals of Medieval Ireland and Wales. The Clonmacnoise Group of Texts (Woodbridge, 1984), especially pp. 207-26.

${ }^{28}$ S.a. 629.
} 
the whole of the Annales Cambriae and in the Irish chronicle record sieges are indicated by obsessio followed by the name of the place besieged and not by the name of the person commanding the defence. ${ }^{29}$ The language used here is suspiciously narrative in character. This entry is followed, in consecutive years, by notices of Catguollaun's victory over Edwin and death. ${ }^{30}$ For what it is worth, none of these three entries names, the king's father or kingdom.

The besieging of Catguollaun on insula Glannauc immediately prior to his victory over Edwin is suspiciously reminiscent of two other island sieges mentioned in $H B$ whose relationship with one another has been discussed by Patrick Sims-Williams. ${ }^{31}$ Both these sieges, Vortimer's siege of Hengest and Horsa on Thanet and Urien's besieging of Theodric on Lindisfarne, ended with the apparently victorious besieger being unexpectedly slain. ${ }^{32}$ In the case of Caedualla, Bede himself tells us of just such a siege, albeit in an oppido municipio rather than on an island and occurring after, rather than before, the great victory over Edwin. Osric, the tragic hero of that siege, was absent from Northumbrian king-lists and left no great reputation behind him. ${ }^{33}$ It would be no surprise, therefore, if the burden of an established narrative trope massaged the details of Caedualla's career into a more familiar and heroic form. A further parallel between these events and the island sieges discussed by Sims-Williams lies in the fate of the head of the besieger. Edwin's head was removed from his corpse and taken to be interred in York where it became the focus of a cult. ${ }^{34}$ Later Welsh tradition seems to have envisaged similar retrievals of the heads of Urien and Brân and of the body of Vortimer. ${ }^{35}$ Sims-Williams even suggests that the parallel between the later Welsh literary traditions and the fate of Edwin's head may not be coincidental since the latter was evidently known in Wales. ${ }^{36}$

Insula Glannauc itself is thought to be the island variously known as Priestholm, Puffin Island, and Ynys Seiriol which lies off Penmôn at the extreme eastern end of Ynys Fôn. Gerald of Wales identifies this place as Enislannach, interpreting the second element as meaning 'a man who inhabits a llan', i.e. an anchorite. ${ }^{37}$ It is more likely that the first element is derived from glân, 'clean, pure or holy', with soft mutation leading to the loss of initial 'g' after ynys. In later tradition Ynys Seiriol was said to have been the burial place of Maelgwn, the son of an earlier Cadwallon, and a major figure in the royal traditions of Gwynedd. ${ }^{38}$ An island of this sort, associated

${ }^{29}$ In the Annals of Ulster, for example, we find in the seventh century, 626.2 Obsesio[sic] Boilg Luatha a nepotibus Neill, 638.1 Obsesio Etin, 641.5 Obsesio Rithe, 680.5 Obsesio Duin Baitte, 681.5 Obsessio Duin Foither, 683.3 Obsesio Duin Att 7 obsession Dúin Duirn, 692.6 Obsesio Duin Deaue Dibsi, 694.4 Obsesio Duin Fother. Of these only the first, possibly, contains a personal rather than a place name (cf. $A U 647.3$ ) and none conform to the formula 'of x in y'.

${ }_{30}$ S.a. 630 and 631.

31 P. Sims-Williams, 'The Death of Urien', Cambrian Medieval Celtic Studies, XXXII (1996), 25-56, esp. 34-38.

$32 \mathrm{HB} 43-44$ and 63 respectively.

33 HE III.9.

34 HE II.20.

35 Sims-Williams, Cambrian Medieval Celtic Studies, XXXII, 45 sqq. It would be interesting to know whether Brân's attack on Ireland could be viewed as an 'island siege'.

${ }^{36}$ Ibid., p. 50.

37 Itinerarium Kambriae, II.7, in Giraldi Cambrensis Opera, ed. J. S. Brewer, J. F. Dimock, and G. F. Warner, Rolls Series (1861-91), vol. 6.

38 Trioedd Ynys Prydein: The Welsh Triads, ed. R. Bromwich (Cardiff, 1978), p. 439. 
with royalty and monasticism, with obvious parallels to Lindisfarne, would lend itself admirably to the development of a version of this legend localized in Gwynedd.

To summarize the argument so far, nothing in the Vita Columbae, Historia Ecclesiastica, or the Irish chronicles would encourage us to locate Caedualla in Gwynedd. The identification of Catguollaun as rex regionis Guenedotae in the Historia Brittonum is an authorial gloss on material otherwise drawn from Northumbrian sources and is a product of the synchronizing tendencies of a writer working two centuries after the events he is describing. The entries in the Annales Cambriae, which may be no earlier than the tenth century, do not identify Catguollaun's origins, and the only one of them to add new information to what can be gleaned from $H E$ has suggestions of legendary character about it, and is only inferentially located in North Wales.

This leaves us with three other categories of Welsh material to explore: pedigrees, epigraphy, and verse. Our ability to understand the nature of Welsh genealogical tracts has increased enormously over the last forty years. The service done by Bartrum in publishing the earliest collections in accessible form and the subsequent analysis of sections of the corpus by a number of scholars, foremost amongst whom was Molly Miller, has clarified, to an extent, some very muddy water. ${ }^{39}$ The earliest surviving genealogical collection from Wales, as we have seen, is that appended to the text of $H B$ preserved in Harleian MSS, 3859. The first of the pedigrees in this collection traces the descent of Owain ap Hywel from the ancient kings of Gwynedd. This pedigree can be reproduced as follows with known obits added in square brackets:

Ouen [988] map Higuel [950] map Catell [909] map Rotri [878] map Mermin [844] map Etthil merch Cinnan [816] map Rotri [754] map Iutguaul map Catgualart [682] map Catgollaun [634/5?] map Catman map Iacob [616] map Beli map Run map Mailcun [547] map Catgollaun lauhir [534]... ${ }^{40}$

The pedigree continues back into legendary material ending with Anna, the cousin of Mary the mother of Jesus Christ, but the earlier Catgollaun is the first person in the pedigree for whom we have any chronological markers. This pedigree was composed c. 954 and thus reflects what the court circle of Owain ap Hywel believed or wished to believe at that date. The earlier obit dates are somewhat suspect, and it is possible that the obituary for Maelgwn (Mailcun) may have been calculated from the Northumbrian king-list since $H B$ synchronizes his reign with the arrival of the Northumbrian king Ida whose rule can be calculated to have begun $c .547 .{ }^{41}$ His father's obituary is recorded only in an abstract of the Annals of Redon (in Brittany) made by Robert of Torigny in the late twelfth century but, as Miller observed, 'it seems, however, to have been presupposed by $H B \S 61$ ', which seems to base a calculation of the time between the coming of the Gwynedd dynasty to North Wales and the floruit of Maelgwn by subtracting the death date of Magnus Maximus from that

\footnotetext{
39 Bartrum, EWGT. Miller's contributions are too numerous to list exhaustively but one might note 'Historicity and the Pedigrees of the Northcountrymen', Bulletin of the Board of Celtic Studies, XXVI (1975), 255-80, 'Date-Guessing and Pedigrees', Studia Celtica, X/XI (1975/76), 96-109, 'Date-Guessing and Dyfed', ibid., XII/XIII (1977/78), 33-61.

40 All the obituary dates save those of the two Catgollauns are derived from the Annales Cambriae.

${ }^{41} H B$ 62. This possibility is discussed by Sims-Williams, Cambrian Medieval Celtic Studies, XXXII, 29-30.
} 
of Catgollaun. ${ }^{42}$ In any case the dates for the floruit of Maelgwn and his father are likely to be broadly correct because of the role of the son as correspondent to Gildas. Though the traditional dating of Gildas' De Excidio to $c$. 540 is ultimately dependent upon Maelgwn's obituary in the Annales Cambriae, the position of Gildas himself as a correspondent of Uinniau, a mid-sixth-century figure himself, demonstrates that we are broadly in the right area. ${ }^{43}$ As Miller noted, however, there are problems in the chronology of the early part of this pedigree. In the latter part of the pedigree the nine generations between the death of Catgualart and that of Ouen map Higuel extend over a period of three hundred and six years, giving a generational average of thirtyfour years, which compares well with Irish dynasties of the time. The century between the deaths of the two Catgollauns, if we accept the date of 634/5 (derived from Bede) for the death of the son of Catman, contains six generations with an average span of sixteen years and eight months, something like half that in the later period. ${ }^{44}$ If we were to take the longer, more realistic average, and work back from $634 / 5$, the death of the older Catgollaun would be pushed back to somewhere around 430 putting Maelgwn into the mid fifth rather than the mid sixth century which is hardly credible on the evidence of Gildas.

Miller's solution to this problem was to seek out hints from Geoffrey of Monmouth's Historia Regum Britanniae and late and legendary genealogical tracts that the kings of Gwynedd may have had an alternative pedigree stretching back not to Maelgwn but to an uncle of his. Her attempt is not entirely convincing. Geoffrey states that the royal line descended not from Maelgwn's son Rhun but from his brother Einion whilst a short notice of marriage in the Jesus College genealogies claims that Catgollaun, his father, had a brother called Einion. ${ }^{45}$ The alternative 'hints' that Miller found provide a series of variants from the 'official' pedigree but are no more in agreement with one another than they are with it.

An alternative proposal is that the second Catgollaun has been inserted at some point by the dynasty, possibly at quite a late date, in an attempt to appropriate Bede's Caedualla. Such a suggestion would allow us to provide solutions for two other problems surrounding seventh-century kings of this line. The first is the statement found in $H B \S 64$ that Catgualart regnante apud Brittones post patrem suum. If we are to take this literally we are left with a problem since we have an obituary in the Annales Cambriae for Catgualart s.a. 682 while $H B \S 65$ claims that the King of Gwynedd at the time of Penda's death (655/6) was Catgabail who appears nowhere in the pedigrees but who may be the Cadauel map Kynuedu of the Triads. ${ }^{46}$ This chronological problem would remain even if we accepted, contra Annales Cambriae, $H B$ 's indication that Catgualart died in the plague which occurred in Oswiu's time

${ }^{42}$ Miller, Studia Celtica, X/XI, p. 103. Robert of Torigny's abstract can be found in J. P. Migne, Patrologiae [latinae] cursus completes, 221 vols (Paris, 1844-64), vol. 202, col. 1323.

${ }_{43}$ D. N. Dumville, 'Gildas and Maelgwn: problems of dating', and 'Gildas and Uinniau', both in Gildas: New Approaches, ed. M. Lapidge and D. N. Dumville (Woodbridge, 1984), pp. 51-60 and pp. 207-14, respectively.

${ }_{44}$ Miller, Studia Celtica, X/XI, 101-09.

${ }^{45}$ Ibid., p. 104.

${ }^{46}$ Bromwich, Trioedd Ynys Prydein, triad 68. 
(i.e. 664) ${ }^{47}$ In all likelihood, however, what we have here is yet another example of the author of $H B$ 's inability accurately to synchronize his Welsh and Northumbrian material, indicating, as Dumville has shown, that the concept of an early 'northern history' covering the affairs of both English and British dynasties lying behind $H B$ is insupportable. ${ }^{48}$ If we accept that Catgualart died in 682 and was the son of Catman rather than Catgollaun this brings the average generation length from the death of the first Catgollaun to 682 up to twenty-four years and eight months, much closer to the acceptable twenty-five to thirty-five year range which we have come to expect from comparison with other dynasties of the period.

This adjustment of the pedigree, and some adjustment is certainly necessary, also provides a solution for another minor problem in the chronology of this dynasty. Whilst Bede's Caedualla is identified with the son of Catman it is necessary to assume that Catman was dead or retired into religion by the early 630s. If we free ourselves from this restraint we can imagine his floruit to have occurred at any point between the death of his own father, in 616, and that of Catgualart in 682. Now it happens that Catman is the only King of this dynasty whose mortuary monument survives. At Llangadwaladr (the 'church of Catgualart') on Ynys Fôn, built into the inside of the north wall of the nave of the parish church there is a stone monument measuring $1.23 \times 0.51 \times 0.01$ metres. $^{49}$ It is decorated simply with a Latin cross and an inscription. The inscription reads:

\section{CATAMANUS REXSAPIENTISI MUSOPINATISIM US OMNIUMREG UM}

Which can be expanded to:

CATAMANUS REX SAPIENTISSIMUS OPINATISIMUS OMNIUM REGEM

\section{King Catamanus, Wisest, Most Renowned of All Kings}

The dating of this memorial has long been considered problematic. It appears to be a funerary monument or grave-marker and the temptation has been to assume that it was produced shortly after the death of the individual commemorated. Identifying this individual with the father of Bede's Caedualla creates chronological difficulties. His death is conventionally placed $c$. 625 , to give his supposed son breathing space before his confrontation with Edwin, yet the inscription on the stone would be more comfortably placed, epigraphically, later in the seventh century. Dating of the stone has been sharply divided between those scholars who have relied upon the presumed

\footnotetext{
${ }^{47}$ David Kirby suggests the possibility of two Catgualarts, one who died in the plague of 664 and who was Catgabail's son and one who died in the plague of 682 who was Catguollaun's: 'British Dynastic History in the Pre-Viking Age', Bulletin of the Board of Celtic Studies, XxvII (1976/78), 95-96. Whilst the death of two kings with the same name, both to plague, within a twenty-year span seems a little unlikely one might perhaps consider a modified version of Kirby's argument and consider whether, rather than having been added to the pedigree, the name 'Catguollaun' was amended from an original 'Catgabail'.

${ }^{48}$ Dumville, Welsh History Review, vIII, 345-54.

${ }^{49}$ The details and description of the stone are taken from the UCL Celtic Inscribed Stones Project http://www.ucl.ac.uk/archaeology/cisp/database/stone/lgadw_1.html. Thi stone is no. 970 in R. A. S Macalister, Corpus Inscriptionum Insularum Celticarum (Dublin, 1945-49), 2 vols, and no. 13 in V. E. Nash-Williams, The Early Christian Monuments of Wales (Cardiff, 1950).
} 
death date of Catamanus and those who have allowed palaeographical and art historical thinking drive their analysis. ${ }^{50}$ These scholars have suggested, perhaps rather uncomfortably, that the monument must be to a long dead king. Amongst this latter group Jackson suggested a date of $c$. 650 and Redknap, more recently, $c$. $660 .^{51}$ A floruit for Catman freed up from the constraints of having to be fitted in before Caedualla would allow these problems to be resolved and might also explain why this church should be associated with both Catman and Catgualart when the traditional chronology would place their deaths nearly sixty years apart. If, as $H B$ claimed, Catgualart followed his father on to the throne and if that father were Catman then nothing would be more natural than for him to erect a memorial chapel or dedicate a monastery to his father's memory. Removing Catgollaun map Catman from the pedigree of the kings of Gwynedd would allow us to solve both the problem of the dating of Catamanus stone and the problem of the short generations in the pedigree at a single stroke.

The final category of evidence, early Welsh verse, is the most problematic. While poems do survive which are ascribed to the sixth and seventh centuries, the earliest manuscripts date to the thirteenth century, and much of the surviving corpus is preserved in later manuscripts still. Before the twelfth century the corpus of genuine written Welsh of any kind that is securely dated is so small that absolute dating of palaeographical or orthographical forms within the pre-1100 period is not possible. ${ }^{52}$ Relative dating sequences have, however, been established but linkage of these to absolute dates remains contentious. ${ }^{53}$ While it is widely accepted that some kind of relationship exists between the corpus of medieval Welsh poetry purporting to originate in the sixth and seventh centuries and the historical contexts of those centuries the extent to which individual poems represent genuine relics of the era, modernized to a greater or lesser extent in transmission, rather than self conscious archaising of a later age, is hotly debated amongst students of the field. The more sceptical view, typified by the work of Graham Isaac, holds that it is hard to see any of our surviving material representing genuine poetry of the pre-Viking Age, whilst more optimistic views, typified by the work of John Koch, argue that by reconstructing the hypothetical early forms of the poems (on the basis of restoring phonological features that had changed between $c .600$ and $c .1200$ ), one can demonstrate that certain individual poems of the corpus make better sense as products of the earlier era. ${ }^{54}$ For our present

\footnotetext{
50 A full list of scholars and the dates they have assayed is provided at the web site noted above.

51 K. H. Jackson, Language and History in Early Britain (Edinburgh, 1953), pp. 160-61, M. Redknap, The Christian Celts: Treasures of Late Celtic Wales (Cardiff, 1991), p. 53. See now P. Sims-Williams, The Celtic Inscriptions of Britain: Phonology and Chronology, c. 400-1200 (Oxford, 2003), pp. 277, 294.

52 D. N. Dumville, 'Palaeographical Considerations in the dating of Early Welsh Verse', Bulletin of the Board of Celtic Studies, XXVII (1976/78), 246-51.

${ }_{53}$ K. H. Jackson, Language and History in Early Britain (Edinburgh, 1953, 2nd edn, Dublin, 1994), passim; J. T. Koch, 'When was Welsh Literature First Written Down?', Studia Celtica, xx/xxI (1985/86), 43-68; P. SimsWilliams, 'Dating the Transition to Neo-Brittonic: Phonology and History, 400-600' in Britain 400-600: Language and History, ed. A. Bammesberger and A. Wollman (Heidelberg, 1990), pp. 217-61; idem, 'The Emergence of Old Welsh, Cornish and Breton Orthography, 600-800: the Evidence of Archaic Old Welsh', Bulletin of the Board of Celtic Studies, XXXVIII (1991), 20-86, and now idem, Celtic Inscriptions.

${ }_{54}$ For a flavour of this debate see J. T. Koch, The Gododdin of Aneirin: Text and context from Dark Age North Britain (Cardiff, 1997), and G. R. Isaac, 'Readings in the History and Transmission of the Gododdin', Cambrian Medieval Celtic Studies, xxxviII (1999), 55-78. I am grateful to both Dr Isaac and Professor Koch, and also to Thomas Clancy and Nerys Ann Jones, for discussions of these problems.
} 
purposes we are primarily concerned with one poem from this corpus, Moliant Cadwallon.

Moliant Cadwallon, apparently a praise poem to 'Catwallawn', survives only in a recension the earliest witness of which is in a manuscript in the hand of the seventeenth-century antiquary, Robert Vaughan of Hengwrt. ${ }^{55}$ Only fifty lines are preserved of what was apparently a longer text. ${ }^{56}$ While such a late first witness to the text should excite caution, and while much of the orthography is quite modern in form, there are some orthographic features present that suggest Vaughan's exemplar, or one of its ancestors, took shape $c .1200$. This confirms that the poem is genuinely medieval but still leaves the terminus ante quem for its production almost six hundred years short of a contemporary witness. Two English translations, by John Koch and Andrew Breeze, have appeared since the text was edited, and the variation between these renditions exemplifies the difficulty inherent in using such material for historical purposes. ${ }^{57}$ For example the words echel in line 10 and llong in line 35 are translated as the common nouns 'axle' and 'ship' by Koch but as proper names Echel (an otherwise unknown exemplary hero) and Llong ( a village between Mold and Chester) by Breeze. Such variation considerably affects the sense of the poem. In line $11 \mathrm{rieu}$ is translated 'kings' (plural) by Koch but 'king' (singular) by Breeze. Line 23, Malgwn hevelit haylon o gwas, is rendered alternatively 'a man like Maelgwn, a noble youth' (Koch) and 'the man like Maelgwn, his the generous man's entitlement' (Breeze). Lines 27-28, kymana Gweithen idan adas | ar wyneb kymry Catwallaun was, 'It is an assembling of an army which suits his nature. | For the honour [lit.'face'] of Wales, Cadwallon's land', (Koch), 'Battle and conflict as may be fit | on the soil of Wales, Cadwallon's land' (Breeze). One could go on. This is not the place, nor is this writer qualified, to evaluate the relative qualities of the translations produced by these two well-established philologists. What is demonstrated is what all scholars of medieval Welsh verse would readily admit: that it is extremely difficult to understand and interpret. The lesson to be learned from this short comparison of the two translations is that historians should be extremely cautious of drawing out narrative detail from such material, particularly if they are working only, or primarily, from translations.

For our present interests we must note that Gwynedd and Môn are mentioned, as are Edwin and a burning of York, and it seems fairly clear that the poet was writing about the killing of Edwin and believed his killer to be, as $H B$ states, a king of Gwynedd. If this verse is genuinely a praise poem for Catwallawn then it provides a contemporary witness that the author of $H B$ was correct in his assessment. Whilst the poem is certainly medieval it is far from certainly seventh-century.

\footnotetext{
${ }^{55}$ British Library, Add. MSS, 14907. For an edition and translation into modern Welsh see R. Geraint Gruffydd, 'Canu Cadwallon ap Cadfan', in Studies in Old Welsh Poetry: Astudiaethau ar Yr Hengerdd, ed. R. Bromwich and R. Brinley Jones (Cardiff, 1978), pp. 30-31.

${ }_{56}$ A few more lines, apparently from the same poem, are also preserved in notes made by Vaughan, preserved in NLW, 9094, fols 26b-28.

${ }^{57}$ The translations are to be found in The Celtic Heroic Age: Literary Sources for Ancient Celtic Europe and Early Ireland and Wales, ed. J. T. Koch, with J. Carey (Oakville, 1994, 3rd edn, Oakville and Aberystwyth, 2000), pp. 360-63, and A. Breeze, 'Seventh-Century Northumbria and a Poem to Cadwallon', NH, XXXviII (2001), 145-52, text at 149-50. A significant proportion of the poem is also translated, in extracts, in Gruffydd's 'In Search of Elmet', Studia Celtica, XxviII (1994), 63-79.
} 
Orthographically it would not be possible to push it back beyond the mid twelfth century although an early text could have been heavily modernized by then. There are also suspicious elements. Graham Isaac has pointed to the large number of future forms (mainly in -awd) suggesting that Cadwallon is 'going to do' things. ${ }^{58} \mathrm{He}$ suggests that this prophetic trope puts Moliant Cadwallon into the same class of vaticinatory poems ascribed to Myrddin or Mab Darogan, and it is certainly the case that Cadwallon developed into one of those 'lost leaders' who would return one day, like Arthur. ${ }^{59}$

The poem is also notable for its use of the term kymry, modern Cymru (< *Combrogi, a nominative plural), 'Wales/the Welsh Nation' ${ }^{60}$ This is the only poem in the whole of the Hengerdd corpus to use this word and it looks suspiciously anachronistic. If we could be certain that the additional lines noted by Vaughan in NLW 9094 were truly integral to the poem we could be certain that the whole was late and fabricated for the first of these lines reads $O$ Gymru dygynneu tan yn tir elued. Not translated by Breeze, this line is rendered, unproblematically so far as one can tell, 'from Wales, to kindle fire in the land of Elmet' by Koch. ${ }^{61}$ Now the term Cymrul Cymry is essentially an ethnic rather than a geographical term in origin and the reading here, which seemingly excludes Elmet, would appear to be unlikely before the equation of Wales and the Welsh within broadly the parameters of the modern principality emerged in the central middle ages. ${ }^{62}$ Further evidence that our poet was too much a Welshman and not enough a Briton may perhaps be found in the place-names mentioned in the poem. Apart from Môn and Gwynedd and the northern locations where the conflict with Edwin is thought to have been executed the other places named are, certainly Caer Caradawc and Porth Ysgewin and perhaps, if we follow Breeze, Llong. Breeze must be right, it would seem, in identifying Caer Caradawc with the hillfort beside Sellack in Ergyng (now in Herefordshire). ${ }^{63}$ Porth Ysgewin is unproblematically Portskewett on the banks of the Severn between Chepstow and Caldicot. Llong, if it is a place-name, is a small village a little to the west of Chester. What marks all of these places out is that they are on the Anglo-Welsh border of the central middle ages (the tenth to twelfth centuries). Indeed line 43 explicitly states that Porth Ysgewin is on the 'border estuary'. Two questions arise here. First, would a Gwynedd eulogist of the seventh century really think of the boundaries of Gwent as a particularly meaningful border? Secondly, even if we allow pan-British sentiment to

\footnotetext{
58 Personal communication.

${ }^{59}$ This vaticinatory classification appears on the CD-ROM Yr Hengerdd: mynegeiriau cyflawn, ed. G. Isaac (Aberystwyth, 2001). For an early example of such vaticination see Armes Prydein: The Prophecy of Britain from the Book of Taliesin, ed. Sir Ifor Williams, English version ed. Rachel Bromwich (Dublin, 1972). For discussions of Cadwallon ap Cadfan's place in such traditions see Graham Thomas' papers, 'Dryll o hen lyfr ysgrifen', Bulletin of the Board of Celtic Studies, XXIII (1970), 309-16, and 'Llinellau o Gerddi I Gadwallon ap Cadfan', ibid., XXV1 (1976), 406-10.

${ }^{60}$ The modern distinction between Cymru 'Wales' and Cymry 'the Welsh', had not emerged in the middle ages.

${ }^{61} \mathrm{Cf}$. Geraint Gruffydd's own translation of this line, 'From Wales kindling a fire in the land of Elfed' in his O’Donnell lecture 'In Search of Elmet', Studia Celtica, XXVIII (1994), 75.

${ }_{62}$ This semantic equation reflects two parallel transformations, the disappearance of British polities and peoples outwith 'Wales' and the increasing aspirations of the descendants of Rhodri Mawr ( $\dagger 878$ ) to rule all of the surviving British-speaking territories. For a good succinct account of the rise of Venedotian aspirations, see T. M. Charles-Edwards, in Brown and Farr, Mercia, pp. 100 sqq.

${ }^{63}$ Breeze, $N H$, XXXVIII, 151.
} 
admit that this, the 'Anglo-Gwentish' border, was in some sense a Venedotian border also, would the eastern neighbours of Gwent and Ergyng have actually been English by $c$. 633. Both Somerset and Herefordshire seem to have remained largely, perhaps entirely, in British hands well into the second half of the seventh century ${ }^{64}$ If, for the sake of argument, we follow Koch and disallow Llong as a place-name then the southeastern location of the two remaining places looks even more suspicious. Diametrically opposed to Môn their place here looks very much like an extremity speaking for the whole in 'Land's End to John O'Groats' fashion. Indeed another poem in the Hengerdd corpus uses the line o gaer clut hyt gaer garadawc, 'from Dumbarton to Sellack', in just such a rhetorical fashion. ${ }^{65}$

A further possible hint of anachronism is the allusion in lines 30-31 to the famous hero Gwallawg bearing responsibility for the equally famous battle of Catraeth. ${ }^{66}$ The allusion here looks as if it is intended as a legendary parallel invoked to enhance the subject's status yet if the poem were genuine Catraeth may well have been within living memory and may not yet have attained the epic proportions which it had by the twelfth century. On a similar note the identification of Edwin as a ruler of the Bernicians may have a whiff of anachronism about it, reflecting Bede's desire to treat the history of Deira and Bernicia as that of the single nation he would have us believe they had become by his time. Edwin, however, was the first Deiran to rule over the Bernicians, something he achieved by killing their King and driving their æthelings abroad. ${ }^{67}$ It must be noted, in addition, that the provision of a genuine English personal name for one of the English leaders, as with Edwin ('Edwin' in MS.) here, is unparalleled in the corpus of Hengerdd poetry, in which the individuality of the English is discounted. This smacks of 'book-learning' ${ }^{68}$

To summarize, this poem, though composed in the medieval period, cannot with any certainty be placed any earlier than the twelfth century and a number of features, particularly its use of the word Cymru, suggest that it belongs to a period when the descendants of Rhodri Mawr ( $\dagger 878$ ) were harbouring aspirations to leadership of the whole of Wales in the face of English aggression. There is no evidence that the traditions it maintains are independent of those promoted by Historia Brittonum. ${ }^{69}$

\footnotetext{
${ }^{64}$ For Somerset, see H. P. R. Finberg, 'Sherborne, Glastonbury and the Westward expansion of Wessex', in idem, Lucerna (1964), pp. 95-115. The first West Saxon king to have had jurisdiction here seems to have been Centwine who ruled from 676 to 685/6. For Magonsæte, the English kingdom which occupied Herefordshire to the left of the Wye, see K. Pretty, 'Defining the Magonsæte', in The Origins of Anglo-Saxon Kingdoms, ed. S. Bassett (Leicester, 1989), pp. 171-83. The first English King of this region seems to have been Merewald, who is likely to have been established here during the rule of his brothers, Wulfhere and Æthelred, over the Mercians, 658-75 and 675-704. For the English take-over of this region see also P. Sims-Williams, Religion and Literature in Western England, c. 600-800 (Cambridge, 1990).

${ }_{65}$ The Taliesin Poems, ed. I. Williams and J. E. Caerwyn Williams (Dublin, 1968), p. 15, 1.48. My attention was drawn to this line by Thomas Clancy.

${ }^{66}$ Although, as Thomas Clancy points out to me, the allusion is so vague as to plausibly relate to some other incident at Catraeth rather then the famous battle celebrated in $Y$ Gododdin.

${ }^{67} H E$ II. 12 and III.1. Deira and Bernicia retained separate dynasties until at least 651 and separate kingships until at least 679 .

${ }^{68}$ James Fraser suggests to me that we might have expected a contemporary borrowing of the English name to preserve all three syllables found in the original Eadwine (OE) or Eduini (L).

${ }_{69}$ A second poem on Cadwallon 'Englynion Cadwallon' or 'Marwnad Cadwallon', also edited by Gruffydd in Bromwich and Jones, Old Welsh Poetry, pp. 34 41, is clearly late and as Gruffydd suggests, pp. 34-35, looks very much as if it is envisaging a symbolic circuit of Wales. The King's patronymic is not given here. See also Rowland, Early Welsh Saga Poetry, pp. 169-73.
} 
The case against the popular identification of Bede's Caedualla and Cadwallon ap Cadfan king of Gwynedd can be summed up as follows:

1. Bede makes no suggestion that Caedualla emanated from outwith the North and it can be inferred from his text that he was based relatively locally to the Deiran and Bernician kingdoms.

2. The Annales Cambriae entries for 629, 630, and 631 which name Catguollaun do not name the King's father or kingdom and the one entry (s.a. 629) which appears to name a place in Gwynedd (insula Glannauc) looks anachronistic in its formulation. Annales Cambriae was not composed in anything like its present form until the mid tenth century and our earliest surviving copy is from $c .1100$.

3. The author of Historia Brittonum has simply added his stock phrase, regis Guendotae regionis, to passages based entirely on his Northumbrian sources, suggesting that he was not here drawing on an independent Venedotian tradition of these events. It should also be noted that he does not provide a patronymic for Catguollaun. ${ }^{70}$

4. The pedigree of the kings of Gwynedd preserved in the tenth-century collection in Harleian MSS, 3859 appears to contain too many generations in the period between the mid sixth century and the mid seventh. The removal of Catgollaun map [Catman], or even the willingness to allow him a later death date than 634/5, would go some way to rectifying this.

5. The poem Moliant Cadwallon is demonstrably late and cannot be taken as independent witness to these events. It should be noted, perhaps, that this is the first Welsh source to explicitly state that Edwin's killer was Cadwallon ap Cadfan and then only in the additional lines noted by Vaughan in NLW $9094 .{ }^{71}$ It is therefore not impossible that this identification is ultimately dependent upon Geoffrey of Monmouth. ${ }^{72}$

The case against the antiquity and reliability of the identification having been laid out it remains to discuss why the author of Historia Brittonum might have started this ball rolling and then to provide an alternative identification.

To understand the motivation of the author of Historia Brittonum one must understand the context in which he was writing and the materials he had before him. There is no longer any scholarly disagreement with the view that $H B$ was composed in the early ninth century and Professor Dumville is probably correct in arguing that the fourth year of King Mermin (829/30), which forms the final point in a chronological reckoning in $\S 16$ of the work, marks the year of publication. ${ }^{73}$ The same evidence, inter alia, makes it equally uncontroversial that the author was writing in, or was a

\footnotetext{
70 The significance of this last point will become apparent below.

${ }^{71}$ Gruffydd, in Bromwich and Jones, Old Welsh Poetry, p. 30.

${ }^{72}$ The Historia Regum Brittaniae of Geoffrey of Monmouth, I: A Single-manuscript Edition from Bern, Burgerbibliotek, MS. 568, ed. Neil Wright (Cambridge, 1984), §§191-98. William of Malmesbury, Gesta Regum Anglorum, ed. R. A. B. Mynors, R. M. Thomson, and M. Winterbottom (Oxford, 1998), §48.4, it should be noted, provided no expansion on Bede's account. Geoffrey may well be the earliest authority to make the identification of Edwin's killer with Cadwallon ap Cadfan absolutely explicit.

73 D. N. Dumville, 'Some aspects of the chronology of the Historia Brittonum', Bulletin of the Board of Celtic Studies, XXv (1972-74), 439-45. If one were to accept Field's defence of Nennius's authorship (Studia Cetica, XXx) then one could, perhaps, infer a date of composition between 809 and 817 .
} 
native of, Gwynedd. The history of that kingdom in the author's life-time had been traumatic. Internecine strife and English aggression, perhaps not unconnected, had riven the kingdom. The Annales Cambriae record a battle at Rhuddlan s.a. 797, presumably between the Venedotians and the Mercians, and the following year record the killing of Caradog king of Gwynedd by the Saxons. ${ }^{74}$ Under the years 813, 814, and 816 warfare between Caradog's son Hywel and Cynan, based on Môn, is noted, culminating in the death of Cynan in the moment of victory. Hywel's subsequent reign, until his death in 825, is dogged with Mercian invasion of his Gwynedd heartland and apparent conquest of his eastern neighbours in Powys. ${ }^{75}$ The turning point in this bleak period of warfare and chaos came with the arrival of a dynastic outsider, Mermin, possibly as an aggressive invader from the Isle of Man. ${ }^{76}$

It seems likely that the aggression shown by Mercian kings following the death of Offa, perhaps insecure in their own legitimacy and seeking validation in victories against the old enemy, formed part of the inspiration that led to the composition of Historia Brittonum. For the historian, one of the frustrating aspects of $H B$ is its failure to give an account of recent, eighth- and early-ninth-century history, particularly in Gwynedd and its neighbouring British kingdoms of Powys and Man. Had our author chosen to include such an account in his work it would perhaps have rivalled Bede's account of seventh- and early-eighth-century Northumbria in producing a coherent and relatively reliable narrative..$^{77}$ That he chose not to do so reflects, in all probability, not an absence of records or traditions available to him, but rather the opposite. He was presenting his audience with material they were not likely to know. His generation had, perhaps for the first time, perceived the English as a clear and present danger to Gwynedd and his historia sought to answer the question, 'how did it come to this?'

The historical narrative of $H B$ ends in the late seventh century at about the time, as we have seen, that the Anglo-Welsh frontier as it existed in the era of the author's youth had been established. In ending with the Northumbrian defeat at Lin Garan in 685 ( $\$ 57)$ he tells the story of the English conquest from its beginnings ( $\$ 31$ ) to the point at which it was checked. ${ }^{78}$ From that day until his own time there was probably little, if any, expansion of English frontiers. ${ }^{79}$ By representing the account of those earlier wars our author was attempting to contextualize the present crisis and to encourage his fellow countrymen (Venedotians, perhaps, rather than Welshmen or Britons) to identify with the struggles of those Britons who had lost their wars with the English in the fifth, sixth, and seventh centuries. His task, in a sense, was not to

\footnotetext{
74 The battle of Rhuddlan is entered in the same year as the death of Offa, which occurred in 796, so we must allow for the possibility that $A C$ s dates may be a year or two out in places.

${ }^{75}$ For a balanced appraisal of the fate of Powys under ninth-century Mercian pressure see P. Sims-Williams, 'Historical Need and Literary Narrative: a Caveat from Ninth-Century Wales', Welsh History Review, XVII (1994), 31-40. For a wider, but similarly balanced, discussion see T. M. Charles-Edwards in Brown and Farr, Mercia, pp. 96-100.

${ }^{76}$ Sims-Williams, Welsh History Review, XvII, 11-20.

77 The word 'relatively' is used advisedly.

${ }^{78}$ For the battle of Lin Garan/Dunnichen,/Nechtanesmere, its context and ramifications, see now J. E. Fraser, The Battle of Dunnichen, 685 (Stroud, 2002).

${ }^{79}$ This is not to say that there was not conflict but it is unlikely that whole kingdoms changed hands during this period.
} 
tell the history of his own people but to convince them of the relevance to their present situation of the history of long dead neighbours. ${ }^{80}$ Because our author was in the business of constructing a link with an alien past we should not expect him to have been able to synchronize his own material and the material drawn from English sources with any great accuracy and his attempts to do so are riven with errors. ${ }^{81}$ His identification of Edwin's bane as a King of Gwynedd appears, on the evidence presented here, to be one of these.

The inspiration, or motivation, to identify the Caedualla of his Northumbrian sources with a king of Gwynedd may be found in the internecine strife that had preceded King Mermin's accession. The warfare between Hywel ap Caradog and Cynan ap Rhodri seems to have reflected rivalry between two branches of the dynasty of Gwynedd represented by Harley pedigrees 3 and 1 respectively. These two branches of the dynasty have been identified by modern scholars with Rhos (with its centre at Degannwy) and Môn. ${ }^{82}$ The apical figure who unites these two pedigrees is En [n]iaun girt, a son of that Cunedag/Cunedda who was said to have brought the dynasty to Gwynedd ( $H B$ 62). The two families who were in conflict in the early ninth century, and whose rivalry may well have gone back into the eighth, claimed descent from Enniaun's sons, Hywel ap Caradog from Eugein and Cynan ap Rhodri from Catgolaun. In their competition for control of Gwynedd it is likely that the two factions would have made much of these two, their earliest mutually exclusive ancestors. While Hywel outlived Cynan, Mermin's claim to be linked to the dynasty (in as much as he had one), was to Cynan, his maternal grandfather according to Harley pedigree 1, and thus he represented the dynasty of Catgolaun map Enniaun. ${ }^{83}$

It is likely that whatever annalistic material coming from the British side our author had before him would not have carried incarnation dates; these having been added to Irish and Welsh chronicles in late medieval or modern times. ${ }^{84}$ It is certain that he made some terrible blunders in synchronizing his Welsh and English material, most notably his identification of Eata, father of King Eadbert of Northumbria (737-58), with Eda Glinmaur who is elsewhere said to have slain the Kings Peretur and Gurci whose Annales Cambriae obituaries appear s.a. $580 .{ }^{85}$ Taken in this light it seems probable that encountering Caedualla in his Northumbrian sources he immediately recognized the famous apical figure of the ruling segment of the royal house of the kingdom of Gwynedd. He was not to know that this apical figure had a floruit in the

\footnotetext{
${ }^{80}$ In this light one can compare the author of Historia Brittonum with the archaeologist Julian Richards whose BBC television series on Britain's past is entitled Meet the Ancestors, presumably to convince the target audience that they have some common interest with long-dead people the very existence of whom they were not previously aware of.

${ }^{81}$ The best catalogue of these is to be found in D. N. Dumville, 'The Historical Value of the Historia Brittonum', Arthurian Literature, vi (1986), 14-24.

${ }_{82}$ Bartrum, EWGT, pp. 9-10.

${ }^{83}$ Ibid. The twelfth- or thirteenth-century Historia Gruffud vab Kenan, ed. D. Simon Evans (Cardiff, 1977), makes Mermin Cynan's son-in-law rather than grandson. Either is possible but its earlier date, barely a century after Mermin's death, should incline us towards the Harley account. See also Sims-Williams, Welsh History Review, XVII, $11-18$.

${ }^{84}$ Dumville, Arthurian Literature, vi, 15.

${ }^{85}$ K. H. Jackson, 'On the Northern British Section in Nennius', in Celt and Saxon: Studies in the Early British Border, ed. N. K. Chadwick (Cambridge, 1963), pp. 43-44.
} 
early sixth century. It was left to other, later, authorities to seek out or create a better synchronization in the person of Cadwallon ap Cadfan.

It remains now to identify an alternative and better placed candidate for Bede's Caedualla rex Brettonum. What is sought is a northcountryman, a neighbour to both Deira and Bernicia, who was appropriately placed to be over-king of both and who had a floruit in the early to mid seventh century. Happily a candidate readily presents himself. Harley pedigree 19 reads:

Catguallaun liu ${ }^{86}$ map Guitcun map Samuil penissel map Pappo post Priten map Ceneu map Gyl $h^{87}{ }^{87}$

This pedigree is clearly related to number 11 in the same collection:

Dunaut map Pappo map Ceneu map Coyl hen

The spelling Coyl is to be preferred to Gyl for the earliest member of these pedigrees as Coyl hen appears in three other pedigrees in this collection, 8:

\section{Urbgen map Cinmauc map Merchiaun map Gurgust map Coil hen}

9:

Guallauc map Laenauc ap Maguic clop map Ceneu map Coyl

And 12:

Gurci ha Peretur mepion Eleuther cascord maur map [Gurgust] letlum map ceneu map Coyl

Harley 10 also includes Coyl hen and, indeed, goes back beyond him. Below Coyl it runs:

Morcant map Coledauc map Morcant bulc map Cincar, braut Bran hen map Dumngual moilmut map Garbaniaun map Coyl hen

Miller has suggested that the higher portions of this pedigree, above Coyl, were added in Wales at a relatively late date ${ }^{88}$ One might note further that it is tempting to suggest that the otherwise remarkable name 'Garbaniaun' [recte Gabraniaun?] originated as a Welsh dynastic label for the Cenél nGabráin dynasty of Dál Riata and does not belong here either. Possibly Dumngual moilmut was, in an earlier version of this material, viewed as the same as Dumngual hen, the apical figure who links Harley pedigrees 6 , of Riderch hen map Tutagual, and 7, of Clinog eitin map Cinbelin. ${ }^{89}$

The information drawn from these pedigrees can be presented as a family tree (see Fig. 1) which makes it clear that Catguallaun is, bearing in mind the doubts surrounding pedigree 10, possibly the last descendant of Coyl hen shown here, a generation younger than any of his collaterals. Coyl hen as an apical figure of northcountry pedigrees, however, has the whiff of legend about him and so we must question his position here. Whilst his historicity is by no means implausible we may wonder whether his position here is as an ancestor of one dynasty, ruling one territory or as a notional link between different dynasties, believed in tenth-century Wales to be

${ }^{86}$ The epithet liu is understood as an Old Welsh form of llyw, literally a plough but with the transferred meaning of 'commander', 'leader', or 'rudder', suggesting a military or ruling role for our man.

${ }_{87}$ Bartrum, $E W G T$, p. 12.

${ }^{88}$ Miller, Bulletin of the Board of Celtic Studies, XXvi, 267.

${ }^{89}$ Bartrum, EWGT, p. 10. 


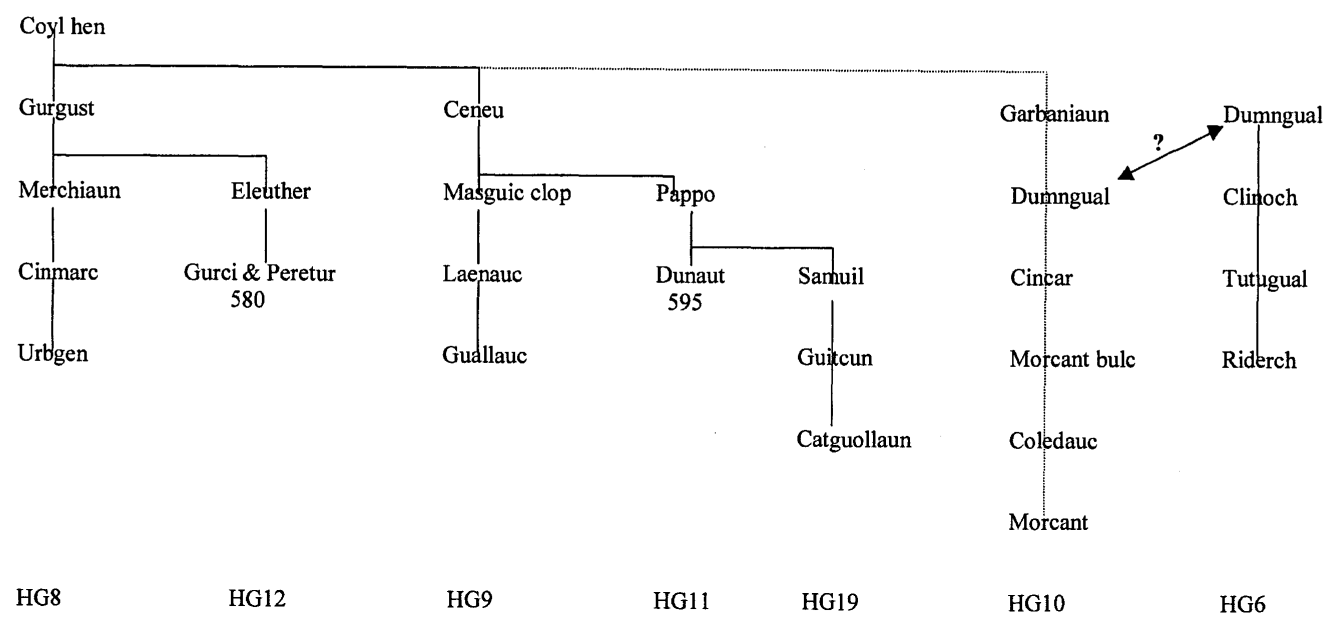

FIGURE 1. The dynasty of Coyl hen in the Harley pedigrees with obituaries supplied from the Annales Cambriae.

associated with one another, descending from Gwrwst, 'Garbaniaun' and Ceneu. Indeed, later pedigrees make Gwrwst a son of Ceneu. ${ }^{90}$

The nature of such an association can in fact be traced to $H B 63$ where the longest interpolation into the Northumbrian king-list, following Hussa regnavit annis vii begins:

Contra illos quattuor reges, Urbgen, et Riderchhen, et Guallac, et Morcant, dimicaverunt.91 Deodric contra illum Urbgen cum filiis dimicabant fortiter. ${ }^{92}$

In illo autem tempore aliquando hostes, nunc cives vincebantur ${ }^{93}$

et ipse conclusit eos tribus diebus et tribus noctibus in insula Metcaud ${ }^{94}$

et dum erat in expeditione, iugulatus est Morcante destinante pro invidia ${ }^{95}$

quia in ipso prae omnibus regibus virtus maxima erat instauratione belli. ${ }^{96}$

Three of these Kings, Urbgen, Guallauc, and Morcant, appear in our family tree at precisely the same generation. This is striking. We need not doubt that the author of $H B$ had a reason for listing these Kings together here, and they may well have worked

\footnotetext{
${ }^{90}$ Bartrum, EWGT, corrects the Harley pedigrees to 'restore' this descent but since they are older than their rivals, also printed by Bartrum, by several centuries this seems unjustified. For an evaluation of the historical value of the different pedigree collections see Miller, Bulletin of the Board of Celtic Studies, XXVI.

${ }_{91}$ 'Against them four kings, Urbgen and Riderch hen and Guallauc and Morcant fought'.

${ }_{92}$ 'Theodric used to fight fiercely against that Urbgen with his sons'. For the ambiguity of whose sons these are (Harleian MSS, 3859 requires them to be Theodric's but this has widely been viewed as an error) see Sims-Williams, Cambrian Medieval Celtic Studies, XXXII, 27, 33. Corrections to the printed Latin in Mommsen and Morris are also from Sims-Williams.

${ }_{93}$ 'Yet at that time sometimes the enemies and sometimes the citizens used to be vanquished'. cf. HE I.16 et ex eo tempore nunc cives nunc hostes uincebant and Gildas, De Excidio Brittaniae \$26, ex eo tempore nunc cives, nunc hostes, uincebant, ed. M. Winterbottom (Chichester, 1978). One cannot help wondering why the author of $H B$ chose to reverse the order of hostes and cives.

${ }_{94}$ 'And he shut them up for three days and three nights on the island of Metcaud.'

${ }^{5}$ 'And while he was on expedition he was killed by Morcant's design for jealousy.'

96 'because, before all kings, he had the greatest skill for renewing war.'
} 
in concert, though that interpretation is not demanded by the text which, since it alludes to the Bernician kings in plural, might be taken to imply a sequence of British opponents. ${ }^{97}$ A coalition, however, is not out of the question and such a circumstance would require its members to be contemporaries but the chances that the leaders of three distinct branches of a dynasty would all belong to the same generation are quite small. It seems as likely, if not more so, that the synchronizing of these three Kings has governed the introduction of a shared common ancestor, Coyl, who may or may not belong to one of the stems. Below the level of the putative sons of Coyl we are probably on safer ground, if not, perhaps, bed-rock. These clusters may represent genuine dynastic groups.

Our historical horizon within the pedigrees does not begin with the three Kings named in $H B$ 63. Of the figures named in these pedigrees the brothers Peretur and Gurci share an obituary in Annales Cambriae s.a. 580 and Dunaut's death is noted in the same chronicle s.a. 595. Where dates in the early section of this chronicle can be cross-checked they are often found to be a year or two too early, for example Dunaut's obituary shares an annal with that of Columcille and with the conversion of the English by Augustine and Mellitus, correctly 597, the death of Edwine is noted at 630, recte 633/4, and of Catguollaun 631, recte 634/5, although after twelve years with no events noted Annales Cambriae, from s.a. 644, seems to be two years ahead of its fellows. ${ }^{98}$ This means that we can probably assume that Dunaut did die in 597 and Peretur and Gurci in 582 or 583. These dates are far from incompatible with the death of Dunaut's great nephew Catguallaun in $634 / 5$ were we to accept an identification with Bede's Caedualla. Indeed the fact that the Catguollaun entries share the inaccuracies of the other 'North British' annals, which the entries relating to Edwin alone do not share, suggests that they belong to the same stratum in the compilation of the chronicle as the former but not the latter.

This analysis also allows us to make a further observation. Discussing the synchronization in the 'Northern Section' of Historia Brittonum Dumville noted that

[the] account of the Lindisfarne confederacy of the four Kings led by Urien, and ascribed by our author to the reign of Theodric of Bernicia (588-592) - although heaven only knows if that is an accurate synchronism - seems to offer a little more than we might expect from a bare annalistic recital. ${ }^{99}$

Despite showing uncharacteristic lack of caution in linking the four Kings to the Lindisfarne campaign, from which, in the text, it is separated by a quotation from Gildas (or Bede citing Gildas) implying some passage of time, and which is ascribed to Urbgen and his (?) sons rather than his allies, Dumville is absolutely right to draw our

\footnotetext{
${ }^{97}$ Cf. Sims-Williams, Cambrian Medieval Celtic Studies, XXXII, 31 for similar anxieties.

${ }^{98}$ It should be noted, however, that Edwin's accession and baptism are entered at the correct dates and therefore certainly derive from a different stratum within the chronicle, deriving, ultimately, from Bede. This fact also explains why the death of Certic appears s.a. 616 when $H B \quad 63$ claims that it was Edwin who expelled him from Elmet. Certic's obituary can probably be rectified to 618/19.

${ }_{99}$ Arthurian Literature, vI, 23. In his paper 'The Origins of Northumbria: some aspects of the British background', in The Origins of Anglo-Saxon Kingdoms, ed. S. Bassett (1989), p. 218, while discussing the same material, Dumville dates Theodric's reign to $572-79$, the dates preferred by Kirby.
} 
attention to the unverifiable nature of this synchronism. ${ }^{100}$ If we were to accept the pedigrees below the level of the putative sons of Coyl as representing distinct dynasties we could perhaps suggest that Urbgen's floruit will have followed the deaths of Gurci and Peretur, 580 recte 582/3, and Guallauc's the death of Dunaut, 595 recte 597. Adomnán bears independent witness that Riderch's floruit overlapped with that of Columba who died in the same year as Dunaut. ${ }^{101}$ There is, so far as one can tell, no chronological control for Morcant. ${ }^{102}$ From this we might infer that once again $H B$ 's synchronism is awry and that the four Kings were in fact contemporaries of Æthelfrith of Bernicia, 592/3-616/17. This should not surprise us for Bede says of Ethelfrith that he 'ravaged the Britons more extensively than any other English ruler,' indeed, 'no ruler or king had subjected more land to the English nation or settled it, having first exterminated or conquered the natives'. ${ }^{103}$ The tale we are told is not one of a great coalition besieging the beach-combers of Bernicia on their sand-bar but one in which one kingdom after another is crushed by a rex fortissimus et gloriae cupidissimus. ${ }^{104}$

Riderch map Tutugual can be located physically thanks to Adomnán who identifies him as a king of petra Cloithe, Dumbarton Rock, who desired to know of Columba whether he should be slain by his enemies or not. The other Kings and their dynasties are more difficult to locate. Suffice to say, however, the evidence of the pedigrees and the Annales Cambriae demonstrates that as late, or as early, as the mid tenth century at least one Welsh scholar believed that there had been a ruler in northern Britain, a member of a dynasty in conflict with the Bernicians, in the early to mid seventh century, who bore the name Caedualla.

${ }^{100}$ Anxiety about these synchronisms had been expressed before, notably by Peter Hunter Blair in 'The Bernicians and their Northern Frontier', in Studies in Early British History, ed. N. K. Chadwick (Cambridge, 1954), pp. $147-52$.

101 Vita Columbae, I.15.

${ }_{102}$ A king named Morken, apparently Riderch's predecessor appears in the twelfth century Vita Kentigerni but the historical value of this material for elucidating earlier centuries is extremely poor. For the text see A. P. Forbes, The Lives of S. Ninian and S. Kentigern (Edinburgh, 1874), pp. 159-242, translation at pp. 33-119. Identifying this character with the Morcant of $H B$ is problematic. See K. H. Jackson, 'The Sources of the Life of St. Kentigern', in Studies in the Early British Church, ed. N. K. Chadwick (Cambridge, 1958), pp. 312-13.

${ }^{103}$ HE I.34. Aedelfrid, qui plus omnibus Anglorum primatibus gentem uastauit Brettonum. ... Nemo enim in tribunes, nemo in regibus plures eorum terras, exterminates uel subingatis indigenis, aut tributaries genti Anglorum aut habitabiles fecit.

${ }^{104}$ For the story of the siege see Sims-Williams, Cambrian Medieval Celtic Studies, XXXII. 